\title{
ПРОТИВОСУДОРОЖНЫЕ СВОЙСТВА КОНДЕНСИРОВАННЫХ ПРОИЗВОДНЫХ ИМИДАЗОБЕНЗИМИДАЗОЛА
}

\author{
Г.В. Придворов, О.Ю. Муха, В.А. Липатов \\ Кафедра фармакологии и биоинформатики, Федеральное государственное бюджетное \\ образовательное учреждение высшего образования «Волгоградский государственный \\ медицинский университет» Минздрава России, \\ 400131, Россия, г. Волгоград, площадь Павших Борцов, д. 1. \\ DOI: 10.19163/MedChemRussia2021-2021-439 \\ E-mail: gleb.pridvorov@gmail.com
}

Активно развивающимся направлением создания новых антиконвульсивных средств является поиск и создание биологически активных соединений на основе гетероциклических структур, в том числе производных бензимидазола [1]. Ранее противосудорожные свойства были изучены у вещества PУ-1205 с каппаопиоидной агонистической активностью [2-4].

Сделан прогноз противосудорожной активности соединений среди ряда производных имидазобензимидазола с помощью системы PASS [5]. Полученный прогноз был верифицирован в тесте максимального электрошока (МЭШ) на мышах, где противосудорожную активность проявили галогенпроизводные имидазобензимидазола под лабораторными шифрами РУ-273 и РУ-285, синтезированные НИИ ФОХ ЮФУ (рис. 1).

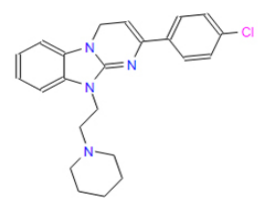

a

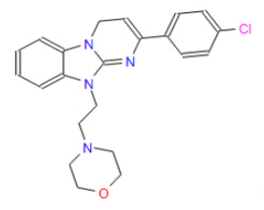

Puс. 1. Вещества PУ-273 (a) и РУ-285 (b), проявивщие противосудорожные свойства в тесте МЭШ

Данные о скаффолдах, реализующих противосудорожные эффекты, а также об уровне указанных видов активности исследованных веществ, могут быть использованы для расширения базы данных эталонов при выполнении прогнозов соответствующих видов активности у новых, в том числе планируемых к синтезу веществ.

\section{Литература}

[1] Васильев, П. М., К. Ю. Калитин, А. А. Спасов, О. Ю. Гречко, В. В. Поройков, Д. А. Филимонов, В.А. Ани-симова. Химико-фармацевтический журнал. 2016, 50 (12), 3-8.

[2] Калитин К. Ю., Спасов А. А. и др. Экспериментальная и клиническая фармакология. 2015, 78 (4), 3-5.

[3] Спасов А. А, Калитин К. Ю.. и др. Экспериментальная и клиническая фармакология. 2018, $81(2), 3-6$.

[4] Спасов А.А., Калитин К. Ю. и др. Бюллетень экспериментальной биологии и медицины. 2015, 160 (9), 320-323.

[5] Filimonov D.A., Lagunin A.A., Gloriozova T.A., Rudik A.V., Druzhilovskii D.S., Pogodin P.V., Poroikov V.V. Chemistry of Heterocyclic Compounds, 2014, 50 (3), 444-457.

$$
-439-
$$

